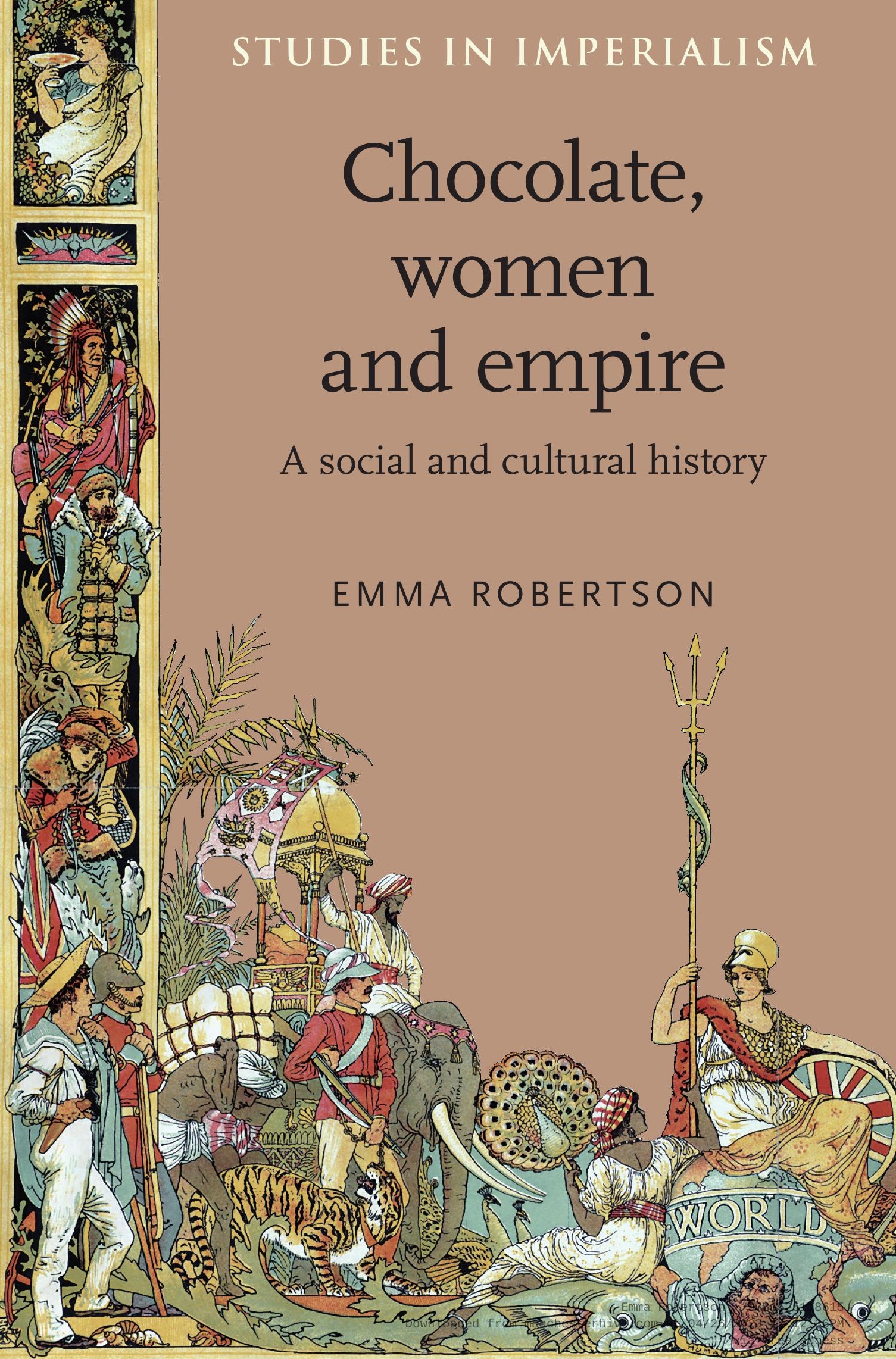




\section{IMPERIES IN-}

general editor John M. MacKenzie

When the 'Studies in Imperialism' series was founded by Professor John M. MacKenzie more than thirty years ago, emphasis was laid upon the conviction that imperialism as a cultural phenomenon had as significant an effect on the dominant as on the subordinate societies'. With well over a hundred titles now published, this remains the prime concern of the series. Cross-disciplinary work has indeed appeared covering the full spectrum of cultural phenomena, as well as examining aspects of gender and sex, frontiers and law, science and the environment, language and literature, migration and patriotic societies, and much else. Moreover, the series has always wished to present comparative work on European and American imperialism, and particularly welcomes the submission of books in these areas. The

fascination with imperialism, in all its aspects, shows no sign of abating, and this series will continue to lead the way in encouraging the widest possible range of studies in the field. Studies in Imperialism is fully organic in its development, always seeking to be at the cutting edge, responding to the latest interests of scholars and the needs of this ever-expanding area of scholarship.

\section{Chocolate, women and empire}

\section{MANCHESTER 1824}

Manchester University Press 
Emma Robertson - 9781526118615 Downloaded from manchesterhive.com at $04 / 26 / 2023$ 12:12:36PM via free access 


\title{
Chocolate, women and empire
}

\section{A SOCIAL AND CULTURAL HISTORY}

\author{
Emma Robertson
}

MANCHESTER

UNIVERSITY PRESS

Manchester 
Copyright (C) Emma Robertson 2009

The right of Emma Robertson to be identified as the author of this work has been asserted by her in accordance with the Copyright, Designs and Patents Act 1988.

Published by Manchester University Press

Altrincham Street, Manchester M1 7ja, UK

WwW.manchesteruniversitypress.co.uk

British Library Cataloguing-in-Publication Data is available

Library of Congress Cataloging-in-Publication Data is available

ISBN 9780719090059 paperback

First published by Manchester University Press in hardback 2009

This paperback edition first published 2013

The publisher has no responsibility for the persistence or accuracy of URLs for any external or thirdparty internet websites referred to in this book, and does not guarantee that any content on such websites is, or will remain, accurate or appropriate. 